ISSN : 2303-1514 | E-ISSN : 2598-5949

\title{
ANALYZING STUDENTS' UNDERSTANDING OF MATHEMATICAL CONCEPT ABOUT TWO-DIMENSIONAL FIGURES AT GRADE III OF ELEMENTARY SCHOOLS IN SERANG
}

\author{
Sellina Ayu Kusumaningrum ${ }^{1}$, Heni Pujiastuti ${ }^{2}$ \\ ${ }^{1,2}$ Universitas Sultan Ageng Tirtayasa, Serang, Indonesia \\ 12225180083@untirta.ac.id, ${ }^{2}$ henipujuastuti@untirta.ac.id
}

\section{ANALISIS PEMAHAMAN KONSEP MATEMATIS MATERI BANGUN DATAR PADA SISWA KELAS III di SDN KOTA SERANG}

\begin{tabular}{|c|c|}
\hline ARTICLE HISTORY & ABSTRACT \\
\hline $\begin{array}{l}\text { Submitted: } \\
\text { 12 Juli } 2021 \\
12^{\text {th }} \text { July } 2021\end{array}$ & $\begin{array}{l}\text { Abstract: The purpose of this research was to analyze the students understanding of } \\
\text { mathematical concepts about two-dimesional figures at the elementary school. This qualitative } \\
\text { descriptive study involved } 40 \text { third grade students at one of the public elementary schools in } \\
\text { Serang. An understanding of mathematical concepts in solving the problem of two-dimensional } \\
\text { figures materials referred to } 5 \text { indicators, namely defining the concept in writing, identifying } \\
\text { examples and non-examples, presenting a concept in the form of models, diagrams, and } \\
\text { symbols, changing one form of representation to another, and recognizing the conditions that } \\
\text { determine a concept. This research found that the percentage for defining the concept in } \\
\text { writing was } 37.5 \% \text {, meaning that students were still not able to define the concept in writing. } \\
\text { Then, the percentage for identifying examples and non-examples was } 32.5 \% \text { meaning that } \\
\text { students were still not able to identify examples and non-examples. The percentage for } \\
\text { presenting a concept in the form of models, diagrams, and symbols was } 77.5 \% \text {, meaning that } \\
\text { students were able to present a concept in the form of models, diagrams, and symbols. After } \\
\text { that, the percentage for changing one form of representation to another was } 27.5 \% \text {, meaning } \\
\text { that students still could not change one form of representation to another. Finally, the } \\
\text { percentage for recognizing the conditions that determine a concept was } 72.5 \% \text {, meaning that } \\
\text { students were able to recognize the conditions that determined a concept. }\end{array}$ \\
\hline
\end{tabular}

Accepted:

28 Agustus 2021

$28^{\text {th }}$ August 2021

Published:

27 Oktober 2021

$27^{\text {th }}$ October 2021
Keywords: concept understanding, mathematics, two-dimensional figure

\begin{abstract}
Abstrak: Tujuan dilakukannya penelitian ini untuk menganalisis pemahaman konsep matematis siswa pada materi bangun datar di jenjang sekolah dasar. Penelitian ini merupakan penelitian deskriptif kualitatif untuk menganalisis pemahaman konsep matematis siswa sekolah dasar dalam menyelesaikan soal bangun datar. Subjek dalam penelitian ini yaitu 40 siswa kelas III di salah satu SD Negeri di kota Serang. Dalam menyelesaikan permasalahan materi bangun datar menunjukan pemahaman konsep matematis yang merujuk pada 5 indikator yaitu:(1) mendefinisikan konsep secara tulisan, yang bisa hanya 37.5\% artinya siswa masih belum mampu mendefinisikan konsep secara tertulis. (2) mengidentifikasikan contoh dan bukan contoh, yang bisa hanya $32.5 \%$ artinya siswa masih belum mampu mengidentifikasikan contoh dan bukan contoh. (3) mempresentasikan suatu konsep dalam bentuk model, diagram, dan symbol, yang bisa sebanyak $77.5 \%$ artinya siswa sudah bisa mempresentasikan suatu konsep dalam bentuk model, diagram, dan symbol. (4) mengubah suatu bentuk representasi ke bentuk lainnya, yang bisa hanya $27.5 \%$ artinya siswa masih belum bisa mengubah suatu bentuk representasi ke bentuk lainnya. (5) mengenal syarat yang menentukan suatu konsep, yang bisa sebanyak $72.5 \%$ artinya siswa sudah mampu mengenal syarat yang menentukan suatu konsep.
\end{abstract}

Kata Kunci: pemahaman konsep, matematika, bangun datar

CITATION

Kusumaningrum, S. A., \& Pujiastuti, A. (2021). Analyzing Students' Understanding of Mathematical Concept about Two-Dimensional Figures at Grade III of Elementary Schools in Serang. Primary: Jurnal Pendidikan Guru Sekolah Dasar, 10 (5), 11421151. DOI: http://dx.doi.org/10.33578/jpfkip.v10i5.8417 . 


\section{PENDAHULUAN}

Matematika merupakan salah satu mata pelajaran yang sangat penting dan diharapkan semua siswa dapat mempelajarinya. Matematika merupakan ilmu yang sering digunakan dalam kegiatan seharihari. Matematika merupakan ilmu dasar yang berkembang pesat, baik dari segi bahan maupun kegunaannya, yang dapat meningkatkan kemampuan siswa untuk berpikir dan mempelajari sesuatu secara logis, sistematis atau berurutan (Fatqurhohman, 2016).

Mata pelajaran matematika merupakan konsep abstrak yang harus dijelaskan secara sistematis. Di bidang matematika, prestasi akademik siswa masih tergolong rendah, yang disebabkan oleh banyak faktor.

Terdapat 4 faktor yang mempengaruhi rendahnya hasil belajar siswa yaitu (1) minat siswa dalam belajar matematika, (2) konsentrasi siswa dalam berlangsungnya pembelajaran, (3) rendahnya konsep pemahaman matematis siswa, dan (4) kedisiplinan dari masing-masing siswa masih sangat kurang (Ardilla \& Hartanto, 2017)

Matematika adalah salah satu ilmu yang membentuk dasar dari ilmu-ilmu lainnya. Matematika merupakan bagian penting dari bidang ilmu pengetahuan. Kebanyakan siswa tidak menyukai matematika. Menurut siswa matematika adalah pelajaran yang sulit karena siswa hanya fokus pada hafalan dan rumus matematika untuk menyelesaikan soal. Mereka percaya menghafal rumus matematika dapat membantu mereka dalam menemukan solusi. Di sisi lain, proses pembelajaran matematika melibatkan proses berpikir.

Ketika memecahkan masalah, siswa memulai proses berpikir di kepala mereka untuk membantu menentukan jawabannya. Kegiatan atau proses berpikir yang dilakukan seseorang untuk memecahkan suatu masalah matematika mengacu pada kemampuan mengingat, mengenali hubungan antar konsep matematika, dan kemudian memunculkan ide. Menghasilkan ide-ide baru dengan menarik kesimpulan yang relevan. Menurut Kusumawardani (2020), keterampilan matematika siswa bukan hanya keterampilan matematika, tetapi juga keterampilan penalaran logis dan berpikir kritis dalam pemecahan masalah.

Memahami konsep matematika bukan hanya mepelajari mata pelajaran matematika saja karena kemampuan memahami konsep matematika memerlukan aturan yang konsisten dengan konsep yang ada untuk menyelesaikan masalah matematika, sehingga siswa dapat menyelesaikan masalah dengan cara yang mutlak dalam pembelajaran matematika. Memahami konsep matematika adalah bagian yang sangat penting dalam belajar matematika. Terdapat pengaruh yang signifikan terhadap kemampuan pemahaman konsep matematika siswa terhadap kinerja akademik (Lilis \& Leonard, 2017).

Kemampuan siswa dalam memahami konsep matematika dapat dilihat dari kemampuan siswa. (1) Mendefinisikan konsep secara lisan dan tertulis. (2) Buat dengan mendefinisikan contoh dan bukan contoh. (3) Gunakan template, diagram, dan simbol untuk mewakili konsep. Ubah satu format ekspresi ke format ekspresi lainnya. (5) Mengenali arti dan interpretasi yang berbeda dari konsep. (6) Mengidentifikasi ciri-ciri konsep dan mengidentifikasi kondisi yang menentukan konsep. (7) Membandingkan dan membedakan konsep (Kusmanto \& Marliyana, 2014)

Memahami dan menguasai suatu konsep merupakan syarat dasar bagi siswa dan mereka perlu untuk menguasai dan memahami konsep matematika sedini mungkin. Ada keterkaitan antara pemahaman konsep matematika yang buruk dengan kinerja siswa yang buruk (Hutagalung, 2017). Perolehan konsep adalah sejauh mana hasil belajar siswa dicapai sehingga mereka dapat menggunakan tulisannya untuk mengidentifikasi, menjelaskan, atau mendefinisikan bagian dari materi pelajaran (Nuhyal Ulia, 2016). Memahami konsep matematika memudahkan siswa untuk bernalar, berkomunikasi, 
menghubungkan, dan memecahkan masalah matematika.

Sekolah dasar adalah sekolah formal di jenjang paling dasar dimana para murid diajarkan ilmu-ilmu dasar yang akan berkaitan dengan ilmu di jenjang selanjutya. Pemahaman konsep matematika dalam jenjang sekolah dasar sangat dibutuhkan lantaran ini dapat membantu siswa dalam memahami pembelajaran serta penyelesaian tugas pada pembelajaran selanjutnya.

Sekolah dasar adalah sekolah pertama yang menerima tumpuan besar dan harapan agar bisa membekali suatu konsep dasar bagi anak-anak (Unaenah \& Sumantri, 2019). Pembelajaran matematika pada sekolah dasar (SD) perlu menerima perhatian yang sungguhsungguh dari aneka macam pihak seperti pendidik, pemerintah, orang tua, juga masyarakat, lantaran pembelajaran matematika pada sekolah dasar adalah peletak konsep dasar yang dijadikan landasan belajar dalam jenjang berikutnya, selain itu pengusaan konsep matematika yang kuat sejak dini juga sangat diperlukan (Mujiati, 2017).

Pemahaman konsep matematis pada jenjang sekolah dasar sangat berpengaruh dalam prose belajar serta dalam menyelesaikan persoalan matematika. Materi bangun datar menjadi salah satu materi dasar yang mulai dipelajari di jenjang sekolah dasar kelas III. Berawal dari konsep mengenai berbagai bentuk yang terbentuk melalui titik atau garis yang membangun 2 dimensi dan memiliki sebuah rumus luas dan juga keliling. Kendala yang terjadi pada materi bangun datar yaitu pada menghitung masalah luas \& juga keliling suatu bangun datar \& ini diyakini lantaran pemahaman konsep matematis murid masih terbilang relatif rendah sebagai akibatnya murid masih tidak mampu dalam menuntaskan sebuah problem bangun datar yang diberikan. .
Sehingga, tujuan dari penelitian ini adalah untuk mengetahui kemampuan siswa dalam meyelesaikan soal bangun datar berdasarkan indikator pemahaman konsep matematika yang nantinya bisa dijadikan bahan evealuasi guru dalam memperbaiki pembelajaran terkait materi bangun datar pada jenjang sekolah dasar.

\section{METODE PENELITIAN}

Penelitian merupakan penelitian kualitatif dan metode penelitian yang di gunakan yaitu metode deskriptif. Penelitian ini berlandaskan dalam filsafat postpositivisme, yaitu dalam objek alamiah yang berkembang apa adanya, tidak dimanipulasi sang peneliti, dan kehadiran peneliti tidak mempengaruhi dinamika dalam objek tersebut (Soehardi et al, 2021). Studi ini dilakukan pada Sekolah Dasar Negeri di Kota Serang Semester Genap Tahun Ajaran 2020/2021. Subyek penelitian ini yaitu sebesar 40 murid kelas III disalah satu Sekolah Dasar Negeri Kota Serang. Teknik sampel yang dipakai yaitu teknik purposive sampling, yaitu pengambilan data menggunakan pertimbangan tertentu (Ilker et al, 2016). Metode penghimpunan data dalam penelitian ini merupakan menggunakan menaruh tes uraian materi bangun datar. Tes uraian tersebut digunakan untuk mendapatkan gambaran pemahaman konsep matematis siswa. Selanjutnya data diolah \& dianalisis dari nilai yang diperoleh murid tadi. Data yang akan diambil pada tes ini merujuk dalam lima indikator pemahan konsep matematis yang sebagai perkara pada pemahaman konsep matematis diantaranya :

Tabel 1 dibawah ini akan mengungkapkan indikator pemahaman konsep dalam instrumen tes pemahaman konsep matematis. 


\section{PRIMARY: JURNAL PENDIDIKAN GURU SEKOLAH DASAR \\ VOLUME 10 NOMOR 5 OKTOBER 2021 \\ ISSN : 2303-1514 | E-ISSN : 2598-5949 \\ DOI : http://dx.doi.org/10.33578/jpfkip.v10i5.8417 . https://primary.ejournal.unri.ac.id/index.php/JPFKIP}

Tabel 1. Indikator Pemahaman Konsep

\begin{tabular}{lrl}
\hline \multicolumn{1}{c}{ Instrumen } & \multicolumn{2}{c}{ Indikator } \\
\hline Tes Pemahaman Konsep Matematis & 1. $\begin{array}{l}\text { Mendefinisikan konsep secara tulisan. } \\
\text { 2. }\end{array}$ \\
& Mengidentifikasi contoh dan bukan \\
contoh. & Mempresentasikan suatu konsep dalam \\
bentuk model. Diagram, dan simbol. \\
4.
\end{tabular}

Pada tabel 2 dibawah ini akan dasar.

menjelaskan spesifikasi penilaian dari tiap indikator pemahaman konsep matematika materi bangun datar pada kelas III sekolah

\section{Tabel 2. Tes Pemahaman Konsep Matematika materi Bangun datar}

Indikator

1. Mendefinisikan konsep secara tulisan.

2. Mengidentifikasikan contoh dan bukan contoh

3. Mempresentasikan suatu konsep dalam bentuk model, diagram, dan simbol

4. Mengubah suatu bentuk representasi ke bentuk lainnya.

\section{Spesifik yang ditetapkan}

Mampu menuliskan pengertian salah satu bangun datar dengan menjelaskan sifatsifat yang dimiliki bangun datar tersebut.

Mampu memilih nama-nama bangun datar yang tersedia, yang memiliki satu sifat yang sama. Selain itu siswa juga diminta untuk menggambar bangun datar yang telah dipilih.

Mampu menggambar 1 sebuah bangun datar yang sesuai dengan sifat-sifat yang telah disebutkan di dalam soal.

Mampu menentukan dan menggambarkan satu bentuk bangun datar yang berbeda dengan mengacu pada sifat-sifat yang telah dimiliki bangun datar lainnya.

5. Mengenal syarat yang Mampu menuliskan sifat-sifat sebuah menentukan suatu konsep bangun datar.

\section{HASIL DAN PEMBAHASAN}

Hasil penelitian berikut adalah nilai yang diperoleh menurut 40 orang murid kelas III yang telah menilik materi bangun datar. Hasil dari penelitian ini berupa nilai tes uraian pemahaman konsep matematis dalam meyelesaikan masalah yang berkaitan bangun datar. Nilai disesuaikan dengan spesifik tiap indikatornya. Indikator pemahaman konsep matematis yang diteliti ialah mendefinisikan 
konsep secara tulisan, mengidentifikasi contoh dan bukan contoh, mempresentasikan suatu konsep dalam bentuk model diagram, dan simbol, mengubah suatu bentuk representasi ke bentuk lainnya dan mengenal syarat yang menentukan suatu konsep.

Pada tabel 3 akan dijelaskan hasil dari

Tes Kemampuan Pemahaman Konsep Matematis :

Tabel 3. Hasil Tes Kemampuan Pemahaman Konsep Matematis

\begin{tabular}{lll}
\hline \multicolumn{1}{c}{ Keterangan } & Nilai \\
\hline Jumlah Siswa & 40 & \\
Nilai Maksimum & 100 \\
Nilai Minimum & 26.67 \\
Rata-rata & 69.91 \\
\hline
\end{tabular}

Pada tabel 4 akan dijelaskan rincian nilai masing-masing Indikator mendefinisikan konsep secara tulisan :

Tabel 4. Indikator mendefinisikan konsep secara tulisan.

\begin{tabular}{ll}
\hline \multicolumn{1}{c}{ Keterangan } & \multicolumn{1}{c}{ Nilai } \\
\hline Rata-rata nilai & 61.25 \\
Persentase nilai di atas rata-rata & $37.5 \%$ \\
Persentase nilai di bawah rata-rata & $62.5 \%$ \\
Nilai Maksimal & 100 \\
Nilai Minimal & 0 \\
\hline
\end{tabular}

Nilai didapat dari soal yang merujuk pada cara siswa dalam mendefinisikan konsep secara tertulis. Soal yang diberikan mengenai pengertian dari salah satu bangun ruang. Dari hasil analisis data pada tabel 4 untuk indikator mendefinisikan konsep secara tulisan jumlah siswa yang diatas rata-rata lebih sedikit dari jumlah siswa yang di bawah rata-rata. Ini menunjukan bahwa siswa masih belum mampu dalam mendefinisikan konsep secara tulisan. Dalam mempelajari matematika siswa harus bisa memahami konsep dengan salah satu indikatornya jika siswa mampu mendefinisikan melalu bahasa mereka sendiri lalu bisa dituliskan pada selembar kertas yang akan menggambarkan bahwa konsep matematika bukan hanya sekedar dihafal atau diingat (Jeheman et al, 2019). Jika seorang siswa masih belum bisa mendefinisikan konsep secara tertulis berarti siswa masih belum memahami isi materi yang ada.

Pada tabel 5 akan dijelaskan rincian nilai masing-masing indikator mengidentifikasi contoh dan bukan contoh.

Tabel 5. Indikator mengidentifikasi contoh dan bukan contoh.

\begin{tabular}{lll}
\hline \multicolumn{1}{c}{ Keterangan } & Nilai \\
\hline Rata-rata nilai & 80 \\
Persentase nilai di atas rata-rata & $32,5 \%$ \\
Persentase nilai di bawah rata-rata & $67,5 \%$ \\
Nilai maksimal & 100 \\
Nilai minimal & 50 \\
\hline
\end{tabular}

Nilai didapat dari soal yang merujuk pada cara siswa mengidentifikasikan contoh dan bukan contoh. Soal yang diberikan yaitu terdapat beberapa pilihan nama bangun datar 
yang tersedia yang memiliki satu sifat yang sama dan siswa juga diminta untuk menggambar bangun datar yang telah dipilih. Dari hasil analisis data pada tabel 5 untuk indikator mengidentifikasi contoh dan bukan contoh jumlah siswa yang diatas rata-rata lebih sedikit dari jumlah siswa yang di bawah rata- rata. Ini menunjukan bahwa siswa masih belum mampu dalam mengidentifikasi contoh dan bukan contoh.

Pada tabel 6 akan dijelaskan rincian
nilai masing-masing $r$ Indikator
mempresentasikan suatu konsep pada bentuk
contoh diagram, \& simbol.

Tabel 6. Indikator mempresentasikan suatu konsep dalam bentuk model diagram, dan simbol.

\begin{tabular}{ll}
\hline \multicolumn{1}{c}{ Keterangan } & Nilai \\
\hline Rata-rata nilai & 77.5 \\
Persentase nilai di atas rata-rata & $77.5 \%$ \\
Persentase nilai di bawah rata-rata & $22.5 \%$ \\
Nilai maksimal & 100 \\
Nilai minimal & 0 \\
\hline
\end{tabular}

Nilai didapat dari soal yang merujuk pada cara siswa mempresentasikan suatu konsep dalam bentuk model, diagram, dan simbol. Soal yang diberikan yaitu siswa diminta menggambarkan sebuah bangun datar dari sifat-sifat yang sudah disebutkan di soal. Dari hasil analisis data pada tabel 6 untuk indikator mempresentasikan suatu konsep dalam bentuk model diagram, dan simbol jumlah siswa yang diatas rata-rata lebih banyak dari jumlah siswa yang di bawah ratarata. Ini menunjukan bahwa siswa sudah mampu dalam mempresentasikan suatu konsep dalam bentuk model diagram, dan simbol

Pada tabel 7 akan dijelaskan rincian nilai masing-masing Indikator mengubah suatu bentuk representasi ke bentuk lainnya.

Tabel 7. Indikator mengubah suatu bentuk representasi ke bentuk lainnya.

\begin{tabular}{ll}
\hline \multicolumn{1}{c}{ Keterangan } & Nilai \\
\hline Rata-rata nilai & 27.5 \\
Persentase nilai di atas rata-rata & $27.5 \%$ \\
Persentase nilai di bawah rata-rata & $72.5 \%$ \\
Nilai maksimal & 100 \\
Nilai minimal & 0 \\
\hline
\end{tabular}

Nilai didapat dari soal yang merujuk pada cara siswa mengubah suatu bentuk represntasi ke bentuk lainnya. Soal yang diberikan yaitu siswa diminta menentukan dan menggambar satu bentuk bangun datar yang berbeda dengan mengacu pada sifat-sifat yang telah dimiliki bangun datar lainnya. Dari hasil analisis data pada tabel 7 untuk indikator mengubah suatu bentuk representasi ke bentuk lainnya jumlah siswa yang diatas rata-rata lebih sedikit dari jumlah siswa yang di bawah rata-rata. Ini menunjukan bahwa siswa masih belum mampu dalam mengubah suatu bentuk representasi ke bentuk lainnya. Hampir semua siswa mampu dengan baik saat menyajikan konsep dalam berbagai bentuk tampilan matematis, dan ada beberapa siswa yang masih mengalami kesalahan. Apabila siswa sudah mampu mengubah bentuk representasi ke bentuk lainnya maka siswa harus mampu mengidentifikasi sifat-sifat suatu konsep dan mengenal syarat yang menentukan suatu konsep ke dalam pertanyaan yang ditanyakan dalam menyelesaikan soal bangun datar tersebut. (Arnidha, 2018)

Pada tabel 8 akan dijelaskan rincian nilai masing-masing Indikator mengenal syarat yang menentukan suatu konsep. 
Tabel 8. Indikator mengenal syarat yang menentukan suatu konsep.

\begin{tabular}{ll}
\hline \multicolumn{1}{c}{ Keterangan } & Nilai \\
\hline Rata-rata nilai & 64.17 \\
Persentase nilai di atas rata-rata & $72.5 \%$ \\
Persentase nilai di bawah rata-rata & $27.5 \%$ \\
Nilai maksimal & 100 \\
Nilai Minimal & 0 \\
\hline
\end{tabular}

Nilai didapat menurut soal yang merujuk dalam cara anak didik mengenal kondisi yang memilih suatu konsep. Soal yang diberikan yaitu menjelaskan beberapa karakteristik-karakteristik atau sifat menurut sebuah bangun datar. Dari hasil analisis data pada tabel 8 untuk indikator mengenal syarat yang menentukan suatu konsep jumlah siswa yang diatas rata-rata lebih banyak dari jumlah siswa yang di bawah rata-rata. Ini menunjukan bahwa siswa sudah mampu dalam mengenal syarat yang menentukan suatu konsep.

Dalam penelitian Nainggolan (2014) menyatakan bahwa masih ada faktor yang mempengaruhi rendahnya pemahaman konsep anak didik antara lain: dalam proses pembelajaran seluruh berpusat hanya dalam pengajar, pengajar menaruh rumus-rumus \& memberi model soal dan penyelesaiannya.

Siswa hanya diarahkan untuk mengerjakan soal menggunakan rumus-rumus yang sudah ada dan berdasarkan pada beberapa yang pernah guru contohkan tanpa tau asal mula rumus tersebut. Dengan pembelajaran yang hanya berpusat pada guru membuat pemahaman konsep matematika menjadai kurang berkembang. Rendahya pemahaman konsep matematis pada materi bangun datar dengan objek siswa kelas III SD harus diperhatikan kempabli karena pemahaman konsep matematika akan berpengaruh pada hasil belajar matematika siswa. Maka dari itu pemahaman konsep yang baik akan mempengaruhi cara berfikir seorang siswa dalam menyelesaikan persoalan matematika.

Banyak rekomendasi berbagai metode pembelajaran yang bisa diterapkan di kelas untuk meningkatkan pemahaman konsep matematis siswa. Hasil penelitian Satrio et al
(2016) dalam penggunaan metode pembelaran Quantum Learning menggunakan kerangka TANDUR dalam pembelajaran matematika berpengaruh positif terhadap kemampuan pemahaman konsep matematis. Selain itu Dona (2016) melakukan penelitian penggunaann aplikasi Geogebra yang sanggup mempengaruhi pemahaman konsep matematis murid khususnya yang menerima pembelajaran Learning cycle 5E. Hasil penelitian Priyambodo (2016) mengambarkan metode pembelajaran Personalized System of Instruction lebih baik menggunakan odel pembelajaran lainnya menggunakan taraf pencapaian yang lebih baik. Berdasarkan penelitian yang sudah dilakukan Achmad et al (2018) disimpulkan bahwa kemampuan pemahaman konsep matematika, keterampilan mengajar pengajar pada mengelola pembelajaran \& kegiatan belajar murid pada kelas V Sekolah Dasar dua Bae semakin tinggi sesudah diterapkannya contoh Realistic Mathematic Education berbantu indera peraga BongPas.

Selain aneka macam metode yang sanggup dipakai pada peningkatan kemampuan pemahaman konsep matematis diharapkan juga media pembelajaran yang sanggup memudahkan murid pada mengkonsepkan suatu bangun datar. Salah satu media yang sanggup digunakan yaitu Tangram. Berdasarkan hasil penelitian yang dilakuakn Andini et al (2019), masih ada kemampuan pemahaman konsep matematis yang lebih baik apabila pembelajaran bangun datar memakai media Tangram. Diharapkan dalam penelitian selanjutnya bisa menyelidiki lebih pada \& menyebarkan secara luas terkait analisis pemahaman konsep matematis murid. 


\section{SIMPULAN DAN REKOMENDASI}

Berdasarkan penelitian dan pembahasan yang sudah diuraikan mengenai pemahaman konsep matematis materi bangun datar pada siswa kelas III SD negeri Tinggar 1 Kota Serang menunjukan bahwa pemahaman konsep matematis siswa masih belum terpenuhi secara maksimal. Dari 5 indikator pemahaman konsep yang di tes, hanya 2 indikator yang nilainya bisa melebih rata-rata. Untuk indikator mendefinisikan konsep secara tulisan banyak siswa yang bisa mendapatkan nilai di atas rata-rata hanya $37,5 \%$ yang menunjukan siswa masih belum mampu mendefinisikan konsep secara tertulis. Untuk indikator mengidentifikasikan contoh dan bukan contoh banyak siswa yang bisa mendapatkan nilai di atas rata-rata hanya $32,5 \%$ yang menunjukan siswa masih belum mampu mengidentifikasikan contoh dan bukan contoh. Untuk indikator mempresentasikan suatu konsep dalam bentuk model, diagram, dan simbol banyak siswa yang bisa mendaptkan nilai di atas rata-rata sebanyak $77,5 \%$ yang menunjukan bahwa siswa sudah bisa mempresentasikan suatu konsep dalam bentuk model, diagram, dan simbol. Untuk indikator mengubah suatu bentuk representasi ke bentuk lainnya banyak siswa yang bisa mendapatkan nilai di atas rata-rata hanya $27,5 \%$ yang menunjukan bahwa siswa masih belum bisa mengubah suatu bentuk representasi ke bentuk lainnya. Dan untuk indikator mengenal syarat yang menentukan suatu konsep banyak siswa yang bisa mendaptkan nilai di atas rata-rata sebanyak $72,5 \%$ yang menunjukan bahwa siswa sudah mampu mengenal syarat yang menentukan suatu konsep.

Pembelajaran matematika di sekolah memerlukan penyesuaian kemampuan untuk memahami berbagai konsep matematika. Bagi para profesional, penting untuk menekankan tugas-tugas yang berkaitan dengan pemahaman konsep matematika, karena pemahaman konsep matematika akan sangat mempengaruhi proses pembelajaran nantinya. Siswa harus mampu mengembangkan kemampuan memahami konsep matematika dan memudahkan siswa untuk bernalar, berkomunikasi, menghubungkan dan memecahkan masalah matematika.

\section{DAFTAR PUSTAKA}

Aang, A., \& Muhaemin, H. (2020). Peningkatan Hasil Belajar Siswa dalam Pembelajaran Matematika melalui Implementasi Model Pembelajaran Problem Based Learning (PBL). PRISMA, 9(2), 213-220.

Andini, N., Aminah, M., \& Handayani, H. (2019). Pengaruh Penggunaan Media Pembelajaran Tangram Terhadap Kemampuan Pemahaman Konsep Matematis Pada Materi Luas Dan Keliling Bangun Datar. Widyagogik: Jurnal Pendidikan dan Pembelajaran Sekolah Dasar, 7(1), 27-37.

Ardila, A., \& Hartanto, S. (2017). Faktor yang mempengaruhi rendahnya hasil belajar matematika siswa mts iskandar muda batam. PYTHAGORAS: Jurnal Program Studi Pendidikan Matematika, 6(2), 12-25.

Arnidha, Y. (2018). Analisis Pemahaman Konsep Matematika Siswa Sekolah Dasar Dalam Penyelesaian Bangun Datar. JPGMI (Jurnal Pendidikan Guru Madrasah Ibtidaiyah AlMultazam), 3(1), 53-61.

Etikan, I., Musa, S. A., \& Alkassim, R. S. (2016). Comparison of convenience sampling and purposive sampling. American journal of theoretical and applied statistics, 5(1), 1-4.

Fahrudin, A. G., Zuliana, E., \& Bintoro, H. S. (2018). Peningkatan Pemahaman 
Konsep Matematika melalui

Realistic Mathematic Education

Berbantu Alat Peraga

Bongpas. ANARGYA: Jurnal

Ilmiah Pendidikan

Matematika, 1(1), 14-20.

Fatqurhohman, F. (2016). Pemahaman

Konsep Matematika Siswa dalam

Menyelesaikan Masalah Bangun

Datar. JIPM (Jurnal Ilmiah

Pendidikan Matematika), 4(2),

127-133.

Fauzia, H. A. (2018). Penerapan Model Pembelajaran Problem Based Learning Untuk Meningkatkan Hasil Belajar Matematika SD. Primary: Jurnal Pendidikan Guru Sekolah Dasar, 7(1), 40-47.

Hutagalung, R. (2017). Peningkatan kemampuan pemahaman konsep matematis siswa melalui pembelajaran guided discovery berbasis budaya toba di smp negeri 1tukka. MES: Journal of Mathematics Education and Science, 2(2).

Jeheman, A. A., Gunur, B., \& Jelatu, S. (2019). Pengaruh Pendekatan Matematika Realistik terhadap Pemahaman Konsep Matematika Siswa. Mosharafa: Jurnal Pendidikan Matematika, 8(2), 191202.

Kusmanto, H., dan Iis, M. (2014). Pengaruh Pemahaman Matematika Terhadap Kemampuan Koneksi Matematika Siswa Kelas Vii Semester Genap SMP Negeri 2 Kasokandel Kabupaten Majalengka. ISSN 2086 - 3918 EduMa Vol.3 No.2 Desember 2014.

Mujiati, M. (2017). Peningkatan Hasil
Belajar Matematika Melalui Metode Discovery Learning Pada Materi Konsep Keliling Dan Luas Bangun Datar Siswa Kelas VA Sd Negeri 009 Pulau Kijang Kecamatan Reteh. Primary: Jurnal Pendidikan Guru Sekolah Dasar, 6(1), 179-189.

Nainggolan. S. (2014). Penerapan Model Pencapaian Konsep Di SMP Negeri 1 Bilang Barat Untuk Peningkatan Kemampuan Pemahaman Konsep Siswa. Jurnal Suluh Pendidikan. 1(1), 18-26.

Novitasari, L., \& Leonard, L. (2017). Pengaruh kemampuan pemahaman konsep matematika terhadap hasil belajar matematika. LPPM UNINDRA

Nurrohmah, S., \& Pujiastuti, H. (2020). Analisis Kemampuan Berpikir Reflektif Siswa dalam Menyelesaikan Soal Matematika Materi Lingkaran. PRISMA, 9(2), 118-127.

Pratiwi, D. D. (2016). Pembelajaran learning cycle $5 \mathrm{E}$ berbantuan geogebra terhadap kemampuan pemahaman konsep matematis. AlJabar: Jurnal Pendidikan Matematika, 7(2), 191-202.

Priyambodo, S. (2016). Peningkatan kemampuan pemahaman konsep matematis siswa dengan metode pembelajaran Personalized System of Instruction. Mosharafa: Jurnal Pendidikan Matematika,5(1), 1017.

Soehardi, F., Putri, L. D., \& Dinata, M. (2021). NVivo Software Training for Young Researchers. Mattawang: Jurnal Pengabdian Masyarakat,2(1), 8- 
13.

Sudarman, S. W., \& Vahlia, I. (2016). Efektifitas Penggunaan Metode Pembelajaran Quantum Learning terhadap Kemampuan Pemahaman Konsep Matematis Mahasiswa. AlJabar: Jurnal Pendidikan Matematika, 7(2), 275-282.

Ulia, N. (2016). Peningkatan pemahaman konsep matematika materi bangun datar dengan pembelajaran kooperatif tipe group investigation dengan pendekatan saintifik di SD. Jurnal Tunas Bangsa, 3(2), 5568.
Unaenah, E., \& Sumantri, M. S. (2019). Analisis Pemahaman Konsep Matematis Siswa Kelas 5 Sekolah Dasar Pada Materi Pecahan. Jurnal Basicedu, 3(1), 106-111.

Zuliana, E. (2017). Penerapan Inquiry Based Learning berbantuan Peraga Manipulatif dalam Meningkatkan Pemahaman Konsep Matematika pada Materi Geometri Mahasiswa PGSD Universitas Muria Kudus. Lectura: Jurnal Pendidikan, 8(1). 35-47. 